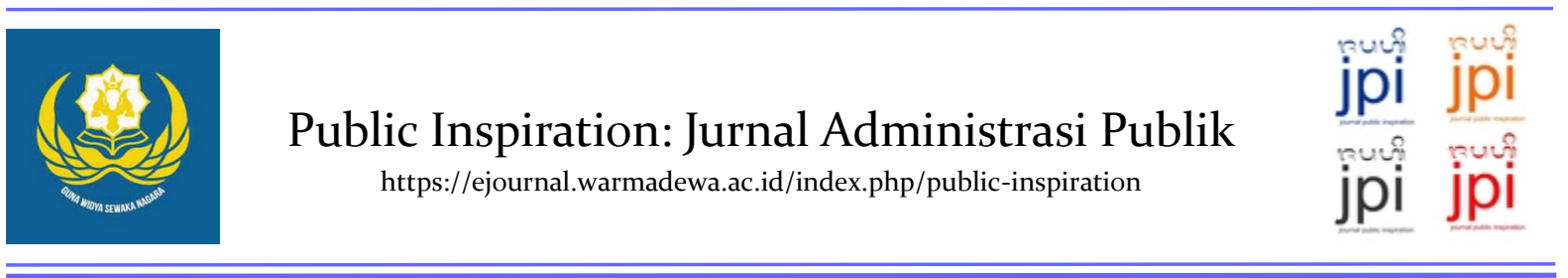

\title{
Implementasi E-Government dalam Proses Pelaporan Surat Pemberita- huan Pajak Daerah di Kabupaten Badung
}

\author{
Ni Made Noviyanti*, A.A. Gede Raka, dan A.A. Ayu Dewi Larantika
}

Program Studi Magister Administrasi Publik Program Pascasarjana Universitas Warmadewa

*Email Corespondence: opikvivo16@gmail.com

\begin{abstract}
How to Cite: Noviyanti, N, M., Raka, A, A, G., Larantika, A, A, A, D. (2021). Implementasi E-Government dalam Proses Pelaporan Surat Pemberitahuan Pajak Daerah di Kabupaten Badung. Public Inspiration: Jurnal Administrasi Publik, 6 (2): 85-96. DOI: https://doi.org/10.22225/pi.6.2.2021.85-96
\end{abstract}

\begin{abstract}
E-Government is an effort to develop electronic-based governance to improve the quality of public services effectively and efficiently, in accordance with Presidential Instruction No. 3 of 2003 concerning e-Government Development Policies and Strategies. Technological developments affect the management of tax administration both for government and taxpayer needs from manual to online systems, thereby saving time, work processes, and paper. By applying online taxes so that good governance is created. The formulation of the problem, namely: 1) How is the implementation of e-Government in the process of reporting Regional Tax Returns to the Badung Regency Government? 2) What are the supporting factors and obstacles to the implementation of e-Government in the process of reporting Regional Tax Returns to the Badung Regency Government? The theory used is the theory of public policy implementation model of Merilee $S$. Grindle and the theory of public policy implementation model of George C. Edwards III. The research approach used a qualitative descriptive. Data collection techniques using observation, interviews, and documentation. The technique of determining informants using purposive sampling. The data analysis technique is descriptive qualitative data analysis, including: data reduction, data display, and drawing conclusions and verification. The results of the research findings concluded that: 1) The implementation of e-Government in the process of reporting Local Tax Returns to the Badung Regency Government has been implemented by implementing an online local tax system through e-SPTPD. 2) The supporting factors for the implementation of e-Government in the process of reporting the Regional Tax Returns to the Badung Regency Government include: the commitment of the Badung Regency Government in public services through e-Government, resources (resources), socialization, internet networks, and taxpayer awareness. While the factors inhibiting the implementation of $e$ -Government in the process of reporting Regional Tax Returns to the Badung Regency Government include: knowledge and awareness of taxpayers and the Covid-19 pandemic.
\end{abstract}

Keywords: e-Government; public policy implementation; regional tax returns

\begin{abstract}
Abstrak
E-Government merupakan upaya mengembangkan penyelenggaraan pemerintahan berbasis elektronik meningkatkan kualitas layanan publik secara efektif dan efisien, sesuai Inpres No. 3 Tahun 2003 tentang Kebijakan dan Strategi Pengembangan e-Government. Perkembangan teknologi mempengaruhi pengelolaan administrasi perpajakan baik keperluan pemerintah maupun wajib pajak dari manual ke sistem online, sehingga menghemat waktu, proses kerja, dan kertas. Dengan diterapkan pajak online sehingga tercipta good governance. Rumusan masalah, yaitu : 1) Bagaimanakah implementasi e-Government dalam proses pelaporan Surat Pemberitahuan Pajak Daerah pada Pemerintah Kabupaten Badung? 2) Apakah faktor-faktor pendukung dan penghambat implementasi e-Government dalam proses pelaporan Surat Pemberitahuan Pajak Daerah pada Pemerintah Kabupaten Badung? Teori yang digunakan adalah teori implementasi kebijakan publik model Merilee S. Grindle dan Teori implementasi kebijakan publik model George C. Edwards III. Pendekatan penelitian menggunakan deskriptif kualitatif. Teknik pengumpulan data menggunakan obvservasi, wawancara, dan dokumentasi. Teknik penentuan informan menggunakan purposive sampling. Teknik analisis data adalah analisis data deskriptif kualitatif, meliputi : reduksi data, display data, serta penarikan kesimpulan dan verifikasi. Hasil temuan penelitian disimpulkan bahwa : 1) Implementasi e-Government dalam proses pelaporan Surat Pemberitahuan Pajak Daerah pada Pemerintah Kabupaten Badung sudah terimplementasi dengan diterapkannya sistem online pajak daerah melalui eSPTPD. 2) Faktor-faktor pendukung implementasi e-Government dalam proses pelaporan Surat Pemberitahuan Pajak Daerah pada Pemerintah Kabupaten Badung meliputi : komitmen Pemerintah Kabupaten Badung dalam pelayanan publik melalui e-Government, resources (sumber daya), sosialisasi, jaringan internet, dan kesadaran Wajib Pajak. Sedangkan faktor-faktor penghambat implementasi e-Government dalam proses pelaporan Surat Pemberitahuan Pajak Daerah pada Pemerintah Kabupaten Badung meliputi : pengetahuan dan kesadaran wajib pajak serta pandemi Covid-19.
\end{abstract}

Kata Kunci: Implementasi Kebijakan Publik; e-Government; Surat Pemberitahuan Pajak Daerah 


\section{Pendahuluan}

E-Government merupakan upaya mengembangkan penyelenggaraan pemerintahan berbasis elektronik dalam meningkatkan kualitas layanan publik secara efektif dan efisien dengan dikeluarkannya Inpres No. 3 Tahun 2003 tentang Kebijakan dan Strategi Pengembangan e-Government. Fungsinya adalah memayungi seluruh kebijakan teknis operasional di bidang e-Government.

Dengan Inpres No. 3 Tahun 2003, bermunculan website pemerintah dicirikan go.id. Penerapan e-Government dengan pemanfaatan TIK di Pemerintah Kabupaten Badung dimulai tahun 2008, dibangunnya website http://www.badungkab.go.id. Penerapan eGovernment tersebut sebatas penyedia akses informasi kepada publik secara lebih luas dan bersifat satu arah. Penerapan e-Government diimplementasikan Pemerintah Kabupaten Badung dalam bidang perpajakan, melalui penerapan pelaporan Surat Pemberitahuan Pajak Daerah (SPTPD) secara online.

Pajak merupakan salah satu sumber penerimaan negara yang penting bagi pelaksanaan dan peningkatan pembangunan nasional sebagai pengamalan Pancasila bertujuan meningkatkan kemakmuran dan kesejahteraan rakyat (Rusjidi, 2008:3). Pajak adalah iuran rakyat kepada kas negara berdasarkan undang-undang (yang dapat dipaksakan) dengan tiada mendapat jasa timbal (kontraprestasi) yang langsung dapat ditunjukkan dan digunakan untuk membayar pengeluaran umum (Mardiamso, 2011:1).

Pajak daerah diatur dalam UU No. 28 Tahun 2009 tentang Pajak Daerah dan Retribusi Daerah. Pajak daerah adalah pajak yang dipungut oleh pemerintah daerah dan digunakan untuk membiayai pengeluaran daerah. Pajak daerah merupakan iuran wajib yang dilakukan oleh orang pribadi atau badan kepada daerah tanpa imbalan langsung yang seimbang, yang dapat dipaksakan berdasarkan peraturan perundang-undangan yang berlaku, yang digunakan untuk membiayai penyelenggaraan pemerintahan daerah dan pembangunan daerah (Mardiamso, 2011:12).

Pemerintah daerah tidak dapat melaksanakan fungsinya secara efektif dan efisien tanpa biaya yang cukup untuk memberikan pelayanan publik dan melaksanakan program pembangunan juga didukung masyarakat berperan serta memenuhi kewajiban pajaknya. Tujuan otonomi daerah dan desentralisasi fiskal adalah meningkatkan kemandirian dan mengurangi ketergantungan fiskal terhadap pemerintah pusat. Meningkatkan kemandirian daerah erat kaitannya dengan kemampuan daerah dalam mengelola Pendapatan Asli Daerah (PAD). Semakin tinggi kemampuan daerah dalam menghasilkan PAD, semakin besar diskresi daerah menggunakan PAD sesuai aspirasi, kebutuhan, dan prioritas pembangunan daerah (Mahmudi, 2010:18).

Ditetapkannya UU No. 28 Tahun 2009 tentang Pajak Daerah dan Retribusi Daerah sebagai upaya mewujudkan otonomi daerah yang luas, nyata, dan bertanggung jawab, maka pembiayaan pemerintahan dan pembangunan daerah berasal dari PAD, bersumber dari pajak daerah. Kemandirian daerah dalam pembiayaan penyelenggaraan pemerintahan di daerah dapat terwujud.

Pengaruh perkembangan dan penerapan TIK juga sampai pada aspek pemerintahan. Salah satunya adalah aspek perpajakan. Adanya relevansi antara pelaksanaan kewajiban perpajakan oleh Wajib Pajak dengan pelayanan perpajakan yang baik agar tercapainya kepatuhan pajak atau tax compliance, khususnya bagi pajak daerah. Perlu adanya integrasi antara administrasi pajak dengan TIK agar tercapainya pelayanan pajak yang modern dan fleksibel sesuai perkembangan jaman.

Perkembangan teknologi yang pesat dalam empat dekade telah memengaruhi pengelolaan administrasi, baik administrasi pemerintahan maupun administrasi bisnis. Perpajakan Indonesia mengakomodir TIK dalam pengelolaan administrasi perpajakan baik keperluan Direktorat Jenderal Pajak (DJP) maupun masyarakat/Wajib Pajak. Bila 
sebelumnya pengelolaan pajak dilakukan secara manual yang membutuhkan banyak waktu dan kertas, kemudian diubah dengan menggunakan TIK yang mengurangi banyak waktu, proses kerja, serta kertas (Pandiangan, 2014:9).

Badan Pendapatan Daerah/Pasedahan Agung Kabupaten Badung merupakan OPD yang memiliki tugas pokok dan fungsi mengelola pendapatan daerah dalam melaksanakan pembangunan daerah. Sejak tahun 2012, beberapa pajak daerah, yaitu: pajak hotel, pajak restoran, pajak hiburan dan pajak pakir berubah sistem pemungutannya dari official assessment menjadi self assessmentyang mengharuskan Wajib Pajak menghitung, memperhitungkan, melaporkan, dan membayar pajaknya sendiri. Dari sisi pelaporan, Wajib Pajak diwajibkan melaporkan pajaknya dengan melaporkan SPTPD (Perbup Badung No. 21 Tahun 2012 tentang Tata Cara Pemungutan Pajak Parkir, Pajak Hotel, Pajak Restoran, Pajak Hiburan, dan Pajak Penerangan Jalan).

Dengan dikeluarkannya Perbup Badung No. 56 Tahun 2013 tentang Online System Pembayaran dan Pelaporan Transaksi Pajak Parkir, Pajak Hotel, Pajak Restoran, dan Pajak Hiburan, Kabupaten Badung sudah menerapkan pembayaran dan pelaporan transaksi pajak secara online. Kemudian dipertegas kembali dengan dikeluarkannya Peraturan Daerah Kabupaten Badung Nomor 2 Tahun 2016 tentang Sistem Online Pajak Daerah berkenaan dengan pemungutan, pelaporan pajak secara online.

Surat Pemberitahuan Pajak Daerah (SPTPD) adalah surat yang digunakan oleh Wajib Pajak untuk melaporkan penghitungan dan/atau pembayaran pajak, objek pajak dan/atau bukan objek pajak, dan /atau harta dan kewajiban sesuai dengan ketentuan peraturan perundang-undangan perpajakan daerah (Pasal 1 angka 11 Peraturan Daerah Kabupaten Badung Nomor 2 Tahun 2016 tentang Sistem Online Pajak Daerah).

Awalnya para wajib pajak melaporkan SPTPD secara manual dengan membawa langsung ke Badan Pendapatan Daerah/Pasedahan Agung Kabupaten Badung ataupun pengambilan SPTPD yang dilakukan oleh petugas pajak. Pengambilan SPTPD yang dilakukan oleh petugas pajak inilah yang menimbulkan kesan negatif, di mana banyak yang beranggapan petugas pajak dapat diberikan imbalan untuk mengambil dan mengurangi pelaporan pajaknya.

Demi meningkatkan kepatuhan dan kemudahan Wajib Pajak dalam melaporkan SPTPD dan meminimalisir kontak antara petugas pajak dan Wajib Pajak, Badan Pendapatan Daerah/Pasedahan Agung Kabupaten Badung menyediakan fasilitas pelaporan SPTPD secara online kepada Wajib Pajak. Sistem tersebut telah dilaksanakan sejak tahun 2012 sampai sekarang, dengan mengakses website www.bapenda.badungkab.go.id. Wajib Pajak dapat melaporkan SPTPD-nya kapan saja dan dari mana saja. Diterapkannya pajak online dengan harapan : 1) mengurangi tingkat denda atas ketidakpatuhan Wajib Pajak, 2) mengefektifkan penerimaan pajak dan mengurangi kebocoran, 3) memudahkan Wajib Pajak dalam pelaporan pajak terutang, dan 4) mengurangi oknum yang menimbulkan penyalahgunaan pelaksanaan pajak daerah.

Jenis pajak yang pembayaran dan penyetoran pajaknya dengan sistem online oleh wajib pajak, meliputi pajak hotel, pajak, restoran, pajak hiburan, pajak reklame, pajak penerangan jalan, pajak mineral bukan logam dan batuan, pajak parkir, pajak air tanah, pajak bumi dan bangunan perdesaan dan perkotaan, serta bea perolehan hak atas tanah dan bangunan (Pasal 5 ayat (2) Perda Kabupaten Badung No. 2 Tahun 2016 tentang Sistem Online Pajak Daerah).

Sistem online menggunakan self assessment atau menghitung sendiri besaran nilai pajak dibayarkan Wajib Pajak. Prinsip self assessment menurut UU Ketentuan Umum Perpajakan, artinya memberikan kepercayaan kepada wajib pajak menghitung, memperhitungkan, membayar, dan melaporkan pajak terutang sesuai perhitungan Wajib Pajak (Zuraida dan Advianto, 2011:5). 
Sistem online pembayaran dan pelaporan pajak daerah di Kabupaten Badung melalui Badan Pendapatan Daerah/Pasedahan Agung Kabupaten Badung dalam penerapan eGovernment dengan memanfaatkan TIK, dengan harapan berdampak terhadap kepatuhan Wajib Pajak, optimalisasi perolehan pajak sehingga meningkatkan PAD, serta penerapan asas transparansi dan akuntabilitas baik terhadap Wajib Pajak maupun pelayanan pemerintah kepada masyarakat.

Berdasarkan uraian tersebut di depan, peneliti tertarik untuk menuangkannya dalam sebuah penelitian, dengan mengangkat judul "Implementasi E-Government dalam Proses Pelaporan Surat Pemberitahuan Pajak Daerah di Kabupaten Badung".

Rumusan masalah dalam penelitian ini adalah : 1) Bagaimanakah implementasi eGovernment dalam proses pelaporan Surat Pemberitahuan Pajak Daerah pada Pemerintah Kabupaten Badung? 2) Apakah faktor-faktor pendukung dan penghambat implementasi $e$ Government dalam proses pelaporan Surat Pemberitahuan Pajak Daerah pada Pemerintah Kabupaten Badung?

Tujuan penelitian adalah : 1) Untuk mengetahui, memahami, dan menganalisis implementasi e-government dalam proses pelaporan Surat Pemberitahuan Pajak pada Daerah pada Pemerintah Kabupaten Badung. 2) Untuk mengetahui, memahami, dan menganalisis faktor-faktor pendukung dan penghambat implementasi e-Government dalam proses pelaporan Surat Pemberitahuan Pajak Daerah pada Pemerintah Kabupaten Badung.

Manfaat penelitian adalah : 1) Bermanfaat bagi perkembangan ilmu pengetahuan di bidang implementasi kebijakan berkaitan e-government dalam pelaporan Surat Pemberitahuan Pajak Daerah. 2) Dapat menjadi referensi bagi peneliti lainnya yang melakukan penelitian dengan objek serupa. 3) Bermanfaat bagi Pemerintah Daerah Kabupaten/Kota dalam memberikan masukan pengambilan kebijakan meningkatkan pelayanan publik pelaksanaan pelaporan Surat Pemberitahuan Pajak Daerah melalui $e$ government. 4) Bermanfaat bagi masyarakat (wajib pajak) memudahkan pelaporan Surat Pemberitahuan Pajak Daerah melalui e-Government.

\section{Konsep}

\section{Implementasi Kebijakan Publik}

Implementasi kebijakan pada prinsipnya adalah cara agar sebuah kebijakan dapat mencapai tujuannya. Untuk mengimplementasikan kebijakan publik, ada dua pilihan langkah, yaitu langsung mengimplementasikan dalam bentuk program atau melalui formulasi kebijakan derivat atau turunan dari kebijakan publik tersebut (Nugroho, 2011:618).

Grindle (1980) menyatakan, implementasi merupakan proses umum tindakan administratif yang dapat diteliti pada tingkat program tertentu. Proses implementasi baru akan dimulai apabila tujuan dan sasaran telah ditetapkan, program kegiatan telah tersusun, dan dana telah siap dan telah disalurkan untuk mencapai sasaran.

Van Meter dan Van Horm (Winarno, 2008:146-147) mendefinisikan implementasi kebijakan publik sebagai tindakan-tindakan dalam keputusan-keputusan sebelumnya, mencakup usaha-usaha mengubah keputusan-keputusan menjadi tindakan-tindakan operasional dalam kurun waktu tertentu maupun dalam rangka melanjutkan usaha-usaha untuk mencapai perubahan besar dan kecil yang ditetapkan oleh keputusan-keputusan kebijakan yang dilakukan organisasi publik diarahkan mencapai tujuan yang telah ditetapkan.

Daniel A. Mazmanian dan Paul Sabatier (Wahab, 2008:65) mengatakan implementasi adalah memahami apa yang senyatanya terjadi sesudah suatu program dinyatakan berlaku/ dirumuskan yang mencakup usaha-usaha mengadministrasikannya maupun menimbulkan akibat/dampak nyata pada masyarakat atau kejadian-kejadian. 
Implementasi kebijakan tidak akan timbul sebelum tujuan-tujuan dan sasaran-sasaran ditetapkan atau diidentifikasi oleh keputusan-keputusan kebijakan. Jadi implementasi merupakan suatu proses kegiatan yang dilakukan oleh berbagai aktor, sehingga pada akhirnya akan mendapatkan suatu hasil yang sesuai dengan tujuan-tujuan atau sasaransasaran kebijakan itu sendiri.

\section{E-Government}

Bank Dunia mengemukakan bahwa e-Government refers to the use by gobernment agencies of information technologies (such as Wide Area Net-works, the internet, and mobile computing) that have the ability to transform relations with cityzens businesses and other arms of government. (Indrajit, (2002: 3).

E-Government merupakan upaya pemerintah memudahkan aktivitas pemerintahan dengan memanfaatkan kemajuan TIK. E-Government merupakan bentuk pelayanan publik dibuat pemerintah bertujuan menjadi penghubung antara kedua belah pihak maupun pihak lain yang berkepentingan. Yu-che dan James Perry (Falih Fuadi dan Bintoro Wardiyanto, 2010:57) berpendapat e-Government merupakan sebuah garis depan dari rencana pemerintah mendukung serta menyediakan informasi dan peningkatan pelayanan masyarakat, pelaku bisnis, pekerja pemerintah, unit-unit pemerintah lain, dan organisasi sektor ketiga.

Janet Caldow (2001) mendefinisikan e-Government bukanlah sebuah perubahan secara fundamental yang berjangka pendek pada pemerintahan dan kepemerintahan dan bukan pula sebagai awal dari permulaan era industrialisasi. Artinya e-Government merupakan sebuah modernisasi pemanfaatan teknologi, bukan sebuah perubahan mendasar dalam sebuah tata pemerintahan berjalan dalam jangka panjang dan bukan membuktikan asal dari sebuah proses pertumbuhan dan perubahan sosial.

E-Government sebagai strategi pemerintah mewujudkan good governance (tata kepemerintahan yang baik). Mark Robinson (Istianto, 2011:102), terdapat istilah sebagai titik sentral pelaksanaan good governance yaitu : 1) akuntabilitas, menyatakan sebagaian besar efektivitas pengaruh dari mereka yang diperintah terdapat orang yang memerintah, 2) legitimasi, berkaitan dengan hak negara menjalankan kekuasaan terhadap warganya dan seberapa jauh kekuasaan dianggap sah diterapkan, dan 3) transparansi, didasarkan pada adanya mekanisme menjamin akses umum kepada pengambilan keputusan.

Jadi e-Government merupakan suatu mekanisme interaksi baru (modern) antara pemerintah dengan masyarakat dan kalangan yang berkepentingan (stakeholder), di mana melibatkan penggunaan teknologi informasi (terutama internet), dengan tujuan memperbaiki mutu (kualitas) pelayanan publik, sehingga lebih efektif, efisien, dan produktif.

\section{Implementasi E-Government}

Implementasi e-Government merupakan suatu proses kegiatan yang dilakukan oleh berbagai aktor, dengan mekanisme interaksi baru (modern) antara pemerintah dengan masyarakat dan kalangan yang berkepentingan (stakeholder), di mana melibatkan penggunaan teknologi informasi (terutama internet), dengan tujuan memperbaiki mutu (kualitas) pelayanan publik, sehingga lebih efektif, efisien, dan produktif, yang pada akhirnya akan mendapatkan suatu hasil yang sesuai dengan tujuan-tujuan atau sasaransasaran kebijakan itu sendiri.

\section{Surat Pemberitahuan Pajak Daerah}

Salah satu sistem pemungutan pajak daerah adalah sistem self assessment, di mana wajib pajak menghitung, membayar, dan melaporkan sendiri pajak daerah yang terutang. Dokumen yang digunakan oleh wajib pajak adalah Surat Pemberitahuan Pajak Daerah (SPTPD). SPTPD merupakan formulir untuk menghitung, memperhitungkan, membayar, dan melaporkan pajak yang terutang. Sesuai UU No. 28 Tahun 2009 tentang Pajak Daerah 
dan Retribusi Daerah, SPTPD adalah surat yang digunakan oleh wajib pajak untuk melaporkan penghitungan dan/atau pembayaran pajak, objek pajak dan/atau bukan objek pajak, dan/atau harta dan kewajiban sesuai dengan ketentuan peraturan perundang-undangan perpajakan daerah. Sedangkan sesuai dengan Peda Kabupaten Badung No. 2 Tahun 2016 tentang Sistem Online Pajak Daerah, e-SPTPD adalah data SPTPD dalam bentuk elektronik yang dibuat oleh Wajib Pajak dengan menggunakan aplikasi e-SPTPD yang disediakan oleh Dinas Pendapatan Daerah/Pasedahan Agung Kabupaten Badung.

Dengan adanya sistem online, wajib pajak dimudahkan dalam melakukan pembayaran dan penyetoran pajaknya. Tata cara pendaftaran SPTPD online, yaitu : 1) wajib pajak mendaftarkan diri memperoleh fasilitas e-SPTPD disediakan Dinas Pendapatan Daerah/ Pasedahan Agung Kabupaten Badung tanpa dipungut biaya, 2) untuk menggunakan fasilitas e-SPTPD, wajib pajak membuat user account pada sistem online SPTPD disediakan Dinas Pendapatan Daerah/Pasedahan Agung Kabupaten Badung, dan 3) wajib pajak yang memanfaatkan fasilitas e-SPTPD tidak perlu menyampaikan formulir SPTPD ke Dinas Pendapatan Daerah/Pasedahan Agung Kabupaten Badung (Pasal 23 Perbup Badung No. 41 Tahun 2016). Sedangkan tata cara penyampaian SPTPD online, yaitu : 1) wajib pajak menyampaikan e-SPTPD melalui website Dinas Pendapatan Daerah/Pasedahan Agung Kabupaten Badung setelah mendaftarkan diri dan memiliki user account, 2) wajib pajak mengisi data digital disediakan melalui sistem e-SPTPD untuk kepentingan palaporan pajak, 3) wajib pajak diberikan bukti penerimaan elektronik sebagai tanda terima penyampaian eSPTPD, 4) bukti penerimaan elektronik sebagai tanda bukti penerimaan yang sah, dan 5) jangka waktu penyampaian e-SPTPD sesuai ketentuan peraturan perundang-undangan (Pasal 25 Perbup Badung No. 41 Tahun 2016).

\section{Metode}

Penelitian mengambil lokasi di Badan Pendapatan Daerah/Pasedahan Agung Kabupaten Badung, mengemban tugas pokok dan fungsi melakukan pemunggutan retribusi, pajak, dan pendapatan lainnya. Alasan memilih lokasi penelitian di Kabupaten Badung, yaitu : 1) Kabupaten Badung merupakan kabupaten dengan PAD terbesar di Provinsi Bali bersumber dari pajak dan retribusi daerah. 2) Kabupaten Badung sudah mengimplementasikan e-Government dalam proses pelaporan Surat Pemberitahuan Pajak Daerah.

Penelitian ini menggunakan pendekatan kualitatif. Moleong (2005: 6), penelitian kualitatif adalah kegiatan penelitian yang bermaksud untuk memahami fenomena tentang apa yang dialami oleh subjek penelitian, seperti: perilaku, persepsi, motivasi, tindakan, dan lain-lain secara holistik, dan dengan cara deskripsi dalam bentuk kata-kata dan bahasa pada konteks khusus yang alamiah dan dengan memanfaatkan berbagai metode alamiah. Saryono (Ismail Nurdin dan Sri Hartati, 2019:75), penelitian kualitatif merupakan penelitian yang digunakan untuk menyelidiki, menemukan, menggambarkan, dan menjelaskan kualitas atau keistimewaan dari pengaruh sosial yang tidak dapat dijelaskan, diukur, atau digambarkan melalui pendekatan kualitatif.

Penelitian kualitatif sebagai upaya mendeskripsikan data dari hasil pengumpulan data yang sahih sesuai tuntutan penelitian kualitatif, yaitu wawancara, observasi, studi dokumen, dan triangulasi, juga berdasarkan analisis data, refleksi data, kajian emik dan etik terhadap data, dan penarikan kesimpulan yang harus memiliki tingkat kepercayaan tinggi berdasarkan ukuran dependability, credibility, transfebility, dan confirmability.

Data penelitian adalah segala fakta dan angka yang dapat dijadikan bahan untuk menyusun suatu informasi (Arikunto, 2002). Sugiyono (2010:4), menjelaskan bahwa jenis data dalam sebuah penelitian ada dua, yaitu data kuantitatif dan data kualitatif.

Jenis data yang digunakan dalam penelitian ini adalah data kualitatif, yaitu peneliti mengamati dan memahami secara langsung dengan mencari informasi-informasi dari orang- 
orang yang mampu memberikan informasi yang tepat dan juga mencari penjelasan dari sumber-sumber lain, seperti buku-buku dan dokumen yang relevan sebagai pelengkap data.

Data kuantitatif yang digunakan meliputi data dari BPS Kabupaten Badung seperti : luas wilayah, jumlah Kecamatan dan Desa/Kelurahan, penduduk, data dari Badan Pendapatan Daerah/Pasedahan Agung Kabupaten Badung seperti : data kepegawaian, data inventaris barang, data jumlah wajib pajak. Sedangkan data kualitatif meliputi hasil wawancara dengan para informan.

Sumber data dalam penelitian adalah subjek dari mana data dapat diperoleh (Arikunto, 2002). Sumber data terbagi menjadi dua, yaitu data primer diperoleh dengan cara melakukan observasi dan wawancara terhadap nara sumber/informan penelitian berkaitan dengan rumusan masalah penelitian dan data sekunder diperoleh dari BPS Kabupaten Badung, Badan Pendapatan Daerah/Pasedahan Agung Kabupaten Badung.

Pada penelitian kualitatif, peneliti sekaligus sebagai instrumen penelitian. Peneliti sebagai human instrument berfungsi menetapkan fokus penelitian, memilih informan sebagai sumber data, melakukan pengumpulan data, reduksi data, menyajikan data, dan membuat kesimpulan atas temuannya. Dalam penelitian kualitatif, tidak ada pilihan lain daripada menjadikan manusia sebagai instrumen penelitian utama, karena segala sesuatunya belum mempunyai bentuk yang pasti. Dalam keadaan yang tidak pasti dan tidak jelas itu, tidak ada pilihan lain dan hanya peneliti itu sendiri sebagai alat satu-satunya yang dapat mencapainya. Di samping peneliti sebagai instrumen utama, instrumen lainnya dalam penelitian ini juga berupa pedoman wawancara, kamera, alat perekam, alat tulis, dan alatalat lainnya.

Dalam suatu penelitian, peneliti harus menentukan teknik pengumpulan data yang paling tepat yang akan digunakan untuk mendapatkan data yang valid dan reliabel. Metode pengumpulan data ialah teknik atau cara-cara yang digunakan oleh peneliti untuk mengumpulkan data. Beberapa teknik pengumpulan data yang akan digunakan dalam penelitian ini adalah 1) observasi, 2) wawancara, dan 3) dokumentasi.

Dalam penelitian ini digunakan teknik pengambilan sampel non random dengan pemilihan informan sesuai prosedur purposive, dengan mengambil data dari sumber yang relevan dengan permasalahan yang diangkat, sehingga menghasilkan data yang dapat dipercaya dan ketepatan hasil penelitian. Sumber data berasal dari para informan yang berjumlah sekitar 15 orang. Informan kunci dalam penelitian ini adalah Kepala Badan Pendapatan Daerah/Pasedahan Agung Kabupaten Badung, Sekretaris Badan Pendapatan Daerah/Pasedahan Agung Kabupaten Badung, Kepala Bidang dan Kepala Sub Bidang pada Badan Pendapatan Daerah/Pasedahan Agung Kabupaten Badung. Informan pendukung dalam penelitian ini adalah Camat, Lurah/Perbekel, serta masyarakat selaku wajib pajak baik yang berdomisili maupun berusaha di Kabupaten Badung.

Analisis data adalah suatu proses atau upaya pengolahan data menjadi sebuah informasi baru agar karakteristik data tersebut menjadi lebih mudah dimengerti dan berguna untuk solusi suatu permasalahan, khususnya yang berhubungan dengan penelitian. Menurut Miles dan Huberman (1992), analisis data kualitatif adalah mereduksi data, menyajikan data, dan menarik kesimpulan. Sedangkan menurut Spradley (1997:117-119), mengartikan analisis data dalam penelitian kualitatif adalah pengujian sistematis terhadap data yang telah dikumpulkan. Tahapan-tahapan kegiatan yang dilakukan dalam analisis data adalah : 1) reduksi data, 2) display/penyajian data, serta 3) penarikan kesimpulan dan verifikasi.

Pemeriksaan terhadap keabsahan data digunakan menyanggah balik dituduhkan kepada penelitian kualitatif yang mengatakan tidak ilmiah, juga sebagai unsur yang tidak terpisahkan dari tubuh pengetahuan penelitian kualitatif (Moleong, 2012:320). Pengujian keabsahan data dilakukan membuktikan apakah penelitian yang dilakukan benar-benar penelitian ilmiah, sekaligus menguji data yang diperoleh. Uji keabsahan data dalam penelitian kualitatif meliputi uji credibility (validitas internal), transferability (validitas 
eksternal), dependability (reliabilitas), dan confirmability (objektivitas) (Sugiyono (2017:270).

Dalam memenuhi keabsahan data penelitian menggunakan triangulasi. Wiliam Wiersma (Sugiyono, 2017:273) memaknai triangulasi dalam pengujian kredibilitas diartikan pengecekan data dari berbagai sumber dengan berbagai cara dan berbagai waktu. Triangulasi yang digunakan yaitu triangulasi sumber dan dilakukan dengan cara mengecek data yang telah diperoleh melalui beberapa sumber dengan teknik yang sama (Sugiyono, 2017:274).

Pemeriksaan terhadap keabsahan data dalam penelitian ini menggunakan teknik triangulasi yaitu dengan memanfaatkan sesuatu di luar data untuk keperluan pengecekan atau sebagai pembanding terhadap data yang telah dikumpulkan. Data primer berupa informasi dari informan kunci dan informan pendukung dibandingkan dengan data sekunder didapat dari data pendukung, yaitu data observasi dan data dokumen.

\section{Hasil Penelitian dan Pembahasan}

\section{Implementasi E-Government dalam Proses Pelaporan Surat Pemberitahuan Pajak Daerah (SPTPD) pada Pemerintah Kabupaten Badung}

Implementasi e-Government dalam proses pelaporan Surat Pemberitahuan Pajak Daerah (SPTPD) pada Pemerintah Kabupaten Badung sudah diterapkan dan dilaksanakan sistem online pajak daerah dengan ditetapkannya Peraturan Daerah Kabupaten Badung Nomor 2 Tahun 2016 tentang Sistem Online Pajak Daerah. Adapun OPD teknis yang melaksanakannya adalah Badan Pendapatan Daerah/Pasedahan Agung Kabupaten Badung yang didukung oleh sumber daya manusia yang cukup memadai baik dari segi jumlah maupun dari segi pendidikan, juga dari segi sarana dan prasarana penunjang tugas operasional baik di kantor maupun ke lapangan juga sudah memadai, dengan mengoptimalkan penggunaan segala sumber daya yang tersedia tersebut dengan sebaikbaiknya. Demikian pula wajib pajak telah menggunakan SPTPD online atau e-SPTPD secara baik, di mana dari tahun 2016 sampai dengan tahun 2019 terjadi peningkatan yang signifikan, kecuali di tahun 2020 terjadi penurunan yang diakibatkan karena pandemi Covid -19 .

\section{Faktor-Faktor Pendukung dan Penghambat Implementasi E-Government dalam Proses Pelaporan Surat Pemberitahuan Pajak Daerah (SPTPD) pada Pemerintah Kabupaten Badung}

Faktor-faktor pendukung implementasi e-Government dalam proses pelaporan Surat Pemberitahuan Pajak Daerah (SPTPD) pada Pemerintah Kabupaten Badung, adalah sebagai berikut. Pertama, Komitmen Pemerintah Kabupaten Badung dalam pelayanan publik melalui e-Government. E-Government merupakan upaya mengembangkan penyelenggaraan pemerintahan yang berbasis elektronik dalam rangka meningkatkan kualitas layanan publik secara efektif dan efisien. E-SPTPD merupakan salah satu cara pemerintah dalam meningkatkan efisiensi dan efektifitas dalam rangka pelaporan pajak daerah setiap bulannya, di mana wajib pajak diberikan layanan pelaporan SPTPD yang praktis, mudah, cepat, dan efisien. Dengan layanan aplikasi e-SPTPD ini proses pelaporan menjadi cepat, dapat dilakukan di mana saja dan kapan saja tanpa wajib pajak harus datang ke Kantor.

Kedua, Resources (sumber daya). Sumber daya merupakan suatu nilai potensi yang dimiliki oleh suatu materi atau unsur tertentu dalam kehidupan, di mana ia dapat meningkatkan kesejahteraan manusia. Sumber daya yang dimiliki oleh Badan Pendapatan Daerah/Pasedahan Agung dalam mengimplementasikan $e$-Government melalui sistem online pajak daerah (e-SPTPD) meliputi sumber daya manusia yaitu para pegawai yang dimiliki yang sudah cukup memadai baik dari segi kualitas maupun kuantitas, serta fasilitas berupa sarana dan prasarana penunjang operasional kegiatan di kantor maupun di lapangan juga sudah cukup memadai. 
Ketiga, Sosialisasi. Sosialisasi memang dibutuhkan oleh masyarakat selaku wajib pajak, guna memberikan pemahaman, manfaat, serta kemudahan dalam pelaporan pajaknya secara online. Sosialisasi dilaksanakan baik melalui tatap muka secara langsung dengan masyarakat wajib pajak, terutama wajib pajak yang memiliki usaha maupun sosialisasi melalui media massa seperti surat kabar atau koran, media elektronik melalui radio, maupun media sosial seperti website yang miliki Badan Pendapatan Daerah/Pasedahan Agung Kabupaten Badung.

Keempat, Jaringan internet. Pelaksananaan sistem online pajak daerah melalui aplikasi e-SPTPD di Kabupaten Badung yang dilaksanakan oleh Badan Pendapatan Daerah/ Pasedahan Agung Kabupaten Badung menggunakan sistem online, di mana jaringan internet menjadi elemen penting dalam pelaksanaannya. Tanpa jaringan internet, maka tidak dapat terlaksananya sistem pelaporan perpajakan secara online.

Kelima, Kesadaran Wajib Pajak. Kesadaran wajib pajak dalam pelaksanaan pelaporan pajak secara online dari tahun ke tahun terus mengalami peningkatan. Berarti kesadaran masyarakat terhadap kewajibannya telah dilaksanakan secara sadar dan lebih memudahkan mereka, sehingga pelayanan publik perpajakan secara online ini dapat lebih efektif dan efisien.

Faktor-faktor penghambat implementasi e-Government dalam proses pelaporan Surat Pemberitahuan Pajak Daerah (SPTPD) pada Pemerintah Kabupaten Badung, adalah sebagai berikut. Pertama, Pengetahuan dan kesadaran wajib pajak. Pengetahuan wajib pajak dalam penerapan sistem online pajak daerah memang perlu ditingkatkan dengan dilaksanakannya sosialisasi, tetapi berkaitan dengan usia yang sudah lanjut maupun penguasaan teknologi informasi dan komunikasi yang kurang bahkan tidak menguasai memang menjadi kendala dan hambatan. Dan juga berkaitan dengan kesadaran masyarakat terhadap kewajibannya dalam pelaporan perpajakan secara online masih ada saja yang belum melaksanakannya dan memenuhi kewajibannya. Memang dibutuhkan waktu dan sinergitas antara Pemerintah dan masyarakat guna mewujudkan pelaksanaan sistem online pajak daerah di Kabupaten Badung.

Kedua, Pandemi Covid-19. Terjadinya pandemi Covid-19 yang melanda dunia bahkan berdampak juga pada Kabupaten Badung, di mana banyak usaha, terutama usaha di sektor jasa pariwisata yang mengalami penutupan bahkan sampai gulung tikar. Hal ini mengakibatkan implementasi e-Government melalui sistem online pajak daerah mengalami hambatan dalam pelaporan pajak secara online, di mana dengan tutupnya usaha masyarakat, sehingga masyarakat enggan melaporkan pajaknya secara online, karena tidak ada transaksi. Sebenarnya masyarakat selaku wajib pajak harus tetap melaporkan kewajibannya, walaupun tidak terdapat transaksi, tetapi tetap melaporkan pajaknya secara online, walaupun nihil.

\section{Implementasi E-Government dalam Proses Pelaporan Surat Pemberitahuan Pajak Daerah (SPTPD) pada Pemerintah Kabupaten Badung}

Implementasi e-Government dalam proses pelaporan Surat Pemberitahuan Pajak Daerah pada Pemerintah Kabupaten Badung berdasarkan isi kebijakan yaitu: 1) jenis manfaat yang akan dihasilkan, 2) derajat perubahan yang diinginkan, 3) kedudukan pembuat kebijakan, 4) siapa pelaksana program, dan 5) sumber daya yang dikerahkan dan lingkungan kebijakan yaitu : 1) kekuasaan, kepentingan, dan strategi aktor yang terlibat, 2) karakteristik lembaga dan penguasa, dan 3) kepatuhan dan daya tanggap pelaksana teori Merilee S. Grindle sudah terimplementasi dengan diterapkannya sistem online pajak daerah melalui eSPTPD, dengan terjadinya peningkatan pelaporan e-SPTPD secara online dari tahun ke tahun oleh wajib pajak, kecuali pada tahun 2020 terjadi penurunan karena adanya pandemi Covid-19 yang melanda dunia.

Berdasarkan isi kebijakan, yang meliputi pertama, kepentingan yang dipengaruhi oleh kebijakan. Semua pihak dipengaruhi dengan diimplementasikannya Perda Kabupaten Badung No. 2 Tahun 2016 tentang Sistem Online Pajak Daerah. Pemerintah Daerah 
Kabupaten Badung melalui Badan Pendapatan Daerah/Pasedahan Agung berkomitmen mengimplementasikan e-Government ini serta masyarakat Kabupaten Badung juga wajib melaksanakannya. Hal ini dapat dilihat dengan terjadinya peningkatan pemanfaatan eSPTPD secara online dari tahun ke tahun.

Kedua, jenis manfaat yang akan dihasilkan. Manfaat dari diimplementasikannya $e$ Government dalam proses pelaporan Surat Pemberitahuan Pajak Daerah (SPTPD) pada Pemerintah Kabupaten Badung, meliputi efektivitas, efisiensi, mudah, cepat, serta bisa diakses oleh wajib pajak di manapun mereka berada untuk melaporkan e-SPTPD-nya asalkan terdapat jaringan internetnya.

Ketiga, derajat perubahan yang diinginkan. Dengan diterapkannya e-SPTPD secara online dari tahun ke tahun pelaporan e-SPTPD secara online semakin tahun semakin meningkat. Dengan demikian derajat perubahan yang diinginkan oleh Pemerintah Kabupaten Badung melalui Badan Pendapatan Daerah/Pasedahan Agung Kabupaten Badung dalam implementasi e-Government berkaitan dengan kewajiban dan kepatuhan wajib pajak sesuai dengan harapan.

Keempat, kedudukan pembuat kebijakan. Kedudukan pembuat kebijakan yang berkaitan dengan implementasi e-Government dalam proses pelaporan Surat Pemberitahuan Pajak Daerah (SPTPD) pada Pemerintah Kabupaten Badung ada pada Badan Pendapatan Daerah/Pasedahan Agung Kabupaten Badung.

Kelima, siapa pelaksana program. Pelaksana dari program e-SPTPD secara online dilaksanakan oleh Badan Pendapatan Daerah/Pasedahan Agung Kabupaten Badung.

Keenam, sumber daya yang dikerahkan. Keadaan sumber daya manusia, sarana dan prasarana, serta pembiayaan pada Badan Pendapatan Daerah/Pasedahan Agung Kabupaten Badung dapat dikatakan cukup memadai baik dari kualitas dan kuantitasnya untuk melaksanakan sistem online pajak daerah ini sesuai dengan peraturan perundang-undangan yang berlaku.

Sedangkan berdasarkan lingkungna kebijakan, yang meliputi pertama, kekuasaan, kepentingan, dan strategi actor yang terlibat. Dengan diterapkannya sistem pajak daerah secara online dari tahun ke tahun kesadaran masyarakat untuk melaporkan e-SPTPD secara online semakin meningkat. Hal ini membuktikan bahwa kekuasaan, kepentingan, dan strategi aktor yang terlibat dalam pembuatan peraturan sistem pajak daerah secara online serta implementasinya sudah dapat berjalan dengan baik dan sesuai dengan harapan semua pihak, karena lebih efektif, efisien, mudah, dan cepat.

Kedua, karakteristik lembaga dan penguasa. Karakteristik lembaga dan penguasa dalam mengimplementasikan e-Government sesuai dengan peraturan perundang-undangan yang berlaku yang didukung oleh komitmen Pemerintah Kabupaten Badung melalui Badan Pendapatan Daerah/ Pasedahan Agung Kabupaten Badung, juga atas dukungan dan peran serta aktif masyarakat Kabupaten Badung selaku wajib pajak.

Ketiga, kepatuhan serta daya tanggap pelaksana. Dalam mengimplementasikan $e$ Government dalam proses pelaporan Surat Pemberitahuan Pajak Daerah pada Pemerintah Kabupaten Badung, Pemerintah Kabupaten Badung melalui Badan Pendapatan Daerah/ Pasedahan Agung harus memperhatikan baik faktor-faktor pendukung maupun penghambat dalam mengimplementasikan e-Government dalam proses pelaporan Surat Pemberitahuan Pajak Daerah pada Pemerintah Kabupaten Badung. Yang sudah baik supaya lebih ditingkatkan lagi dan yang masih kurang, supaya dilaksanakan pembenahan/perbaikan, sehingga dapat memberikan pelayaan publik yang prima berkaitan dengan pelayanan eSPTPD secara online, dengan harapan pelayanan dapat lebih efektif, efisien, mudah, dan cepat, serta dapat diakses dari mana saja. 


\section{Faktor-Faktor Pendukung dan Penghambat Implementasi E-Government dalam Proses Pelaporan Surat Pemberitahuan Pajak Daerah (SPTPD) pada Pemerintah Kabupaten Badung}

Faktor-faktor pendukung dan penghambat implementasi e-Government dalam proses pelaporan Surat Pemberitahuan Pajak Daerah pada Pemerintah Kabupaten Badung berdasarkan teori George C. Edwards III, yang meliputi : communication (komunikasi), resources (sumber daya), dispositions (disposisi), dan bureaucratic structure (struktur birokrasi) dipengaruhi baik dari internal Badan Pendapatan Daerah/Pasedahan Agung Kabupaten Badung maupun berasal dari eksternal di luar Badan Pendapatan Daerah/ Pasedahan Agung Kabupaten Badung yaitu masyarakat Kabupaten Badung selaku wajib pajak, maupun instansi lain penyedia jasa layanan penunjang pelaksanaan e-SPTPD secara online.

Communication (komunikasi). Terjalinnya komunikasi yang baik dan optimal baik secara internal maupun eksternal pada Badan Pendapatan Daerah/Pasedahan Agung Kabupaten Badung, faktor-faktor yang menghambat terlaksananya implementasi $e$ Government dalam proses pelaporan Surat Pemberitahuan Pajak Daerah pada Pemerintah Kabupaten Badung dapat segera dicarikan solusinya.

Resources (sumber daya). Dengan peningkatan kapasitas baik berupa penyegaran dengan pendidikan dan pelatihan baik dilaksanakan secara internal melalui on the job training di Badan Pendapatan Daerah/Pasedahan Agung Kabupaten Badung maupun pendidikan dan pelatihan yang dilaksanakan secara eksternal yang dilakukan baik oleh Kementerian Keuangan, Direktorat Jenderal Pajak, maupun instansi terkait.

Dispositions (disposisi). Dengan semua unsur bahu membahu pada Badan Pendapatan Daerah/ Pasedahan Agung Kabupaten Badung mulai dari unsur pimpinan sampai staf bawahan menguasai mekanisme e-SPTPD secara online diharapkan e-SPTPD berjalan sesuai dengan mekanisme dan ketentuan peraturan yang berlaku. Apabila ada masyarakat yang membutuhkan pelayanan dan memohon bantuan karena ketidaktahuannya maupun karena keterbatasan pemahaman dan pengetahuan masyarakat, dapat segera ditangani, karena semua pegawai memahami dan mengetahui mekanisme e-SPTPD tersebut.

Bureaucratic structure (struktur birokrasi). Badan Pendapatan Daerah/Pasedahan Agung Kabupaten Badung dibentuk berdasarkan Peraturan Daerah Kabupaten Badung Nomor 20 Tahun 2016 tentang Pembentukan dan Susunan Perangkat Daerah Kabupaten Badung, sehingga tugas-tugas Pemerintah Daerah Kabupaten Badung telah dibagi habis sesuai dengan struktur organisasi yang ada yang dilaksanakan oleh OPD teknis yang membidanginya.

Faktor-faktor pendukung implementasi e-Government dalam proses pelaporan Surat Pemberitahuan Pajak Daerah pada Pemerintah Kabupaten Badung meliputi : komitmen Pemerintah Kabupaten Badung dalam pelayanan publik melalui e-Government, resources (sumber daya), sosialisasi, jaringan internet, serta kesadaran kewajiban pajak. Sedangkan faktor-faktor penghambat implementasi e-Government dalam proses pelaporan Surat Pemberitahuan Pajak Daerah pada Pemerintah Kabupaten Badung meliputi : pengetahuan dan kesadaran wajib pajak serta pandemi Covid-19.

\section{Simpulan}

Berdasarkan hasil temuan penelitian dan pembahasan dapat disimpulkan, yaitu : 1) Implementasi e-Government dalam proses pelaporan Surat Pemberitahuan Pajak Daerah pada Pemerintah Kabupaten Badung sudah terimplementasi dengan diterapkannya sistem online pajak daerah melalui e-SPTPD, dengan terjadinya peningkatan pelaporan e-SPTPD secara online dari tahun ke tahun oleh wajib pajak, kecuali pada tahun 2020 terjadi penurunan karena adanya pandemi Covid-19 yang melanda dunia. 2) Faktor-faktor pendukung implementasi e-Government dalam proses pelaporan Surat Pemberitahuan 
Pajak Daerah pada Pemerintah Kabupaten Badung meliputi : komitmen Pemerintah Kabupaten Badung dalam pelayanan publik melalui e-Government, resources (sumber daya) yang dimiliki baik berupa sumber daya manusia maupun sarana prasarana sudah memadai, sosialisasi melalui tatap muka maupun media massa dan media elektronik, jaringan internet yang cukup memadai, dan kesadaran Wajib Pajak terhadap kewajibannya telah dilaksanakan. Sedangkan faktor-faktor penghambat implementasi e-Government dalam proses pelaporan Surat Pemberitahuan Pajak Daerah pada Pemerintah Kabupaten Badung meliputi : pengetahuan dan kesadaran wajib pajak serta pandemi Covid-19.

\section{Daftar Pustaka}

Arikunto, Suharsimi. 2002. Prosedur Penelitian Suatu Pendekatan Praktek. Jakarta : Rineka Cipta

Grindle, Merilee S. (ed). 1980. Politics and Apolicy Implementation in The Third World. New Jersey : Princetown University Press. http://www.badungkab.go.id

Instruksi Presiden Nomor 3 Tahun 2003 tentang Kebijakan dan Strategi Pengembangan eGovernment

Mahmudi. 2010. Manajemen Keuangan Daerah. Jakarta : Erlangga

Mardiamso. 2011. Perpajakan Edisi Revisi. Yogyakarta : Andi

Miles, Matthew B dan A. Michael Huberman. 1992. Analisis Data Kualitatif. Diterjemahkan oleh Tjetjep Rohendi Rohidi. Jakarta : UI-Press

Moleong, Lexi J. 2005. Metodologi Penelitian Kualitatif. Bandung : Remaja Rosdakarya

Nugroho, Riant. 2011. Public Policy : Dinamika Kebijakan - Analisis Kebijakan - Manajemen Kebijakan. Jakarta : Elex Media Komputindo

Nurdin, Ismail dan Sri Hartati. 2019. Metodologi Penelitian Sosial. Surabaya : Media Sahabat Cendekia

Pandiangan, Liberti. 2014. Administrasi Perpajakan. Jakarta : Erlangga

Peraturan Bupati Badung Nomor 21 Tahun 2012 tentang Tata Cara Pemungutan Pajak Parkir, Pajak Hotel, Pajak Restoran, Pajak Hiburan, dan Pajak Penerangan Jalan

Peraturan Bupati Badung Nomor 56 Tahun 2013 tentang Online System Pembayaran dan Pelaporan Transaksi Pajak Parkir, Pajak Hotel, Pajak Restoran, dan Pajak Hiburan

Peraturan Bupati Badung Nomor 41 Tahun 2016 tentang Peraturan Pelaksanaan Peraturan Daerah Kabupaten Badung Nomor 2 Tahun 2016 tentang Sistem Online Pajak Daerah

Peraturan Daerah Kabupaten Badung Nomor 2 Tahun 2016 tentang Sistem Online Pajak Daerah

Rusjidi, Muhammad. 2008. PBB, BPHTB, dan Bea Materai. Jakarta : Indeks

Spradley, James P. 1997. Metode Etnografi. Yogyakarta : Tiara Wacana

Sugiyono. 2010. Metode Penelitian Pendidikan Pendekatan Kualitatif, Kuantitatif, dan R\&D. Bandung : Alfabeta

----. 2017. Metode Penelitian Kombinasi (Mixed Methods). Bandung : Alfabeta

Undang-Undang Nomor 28 Tahun 2009 tentang Pajak Daerah dan Retribusi Daerah

Wahab, Solichin Abdul. 2008. Pengantar Analisis Kebijakan Publik. Malang : Universitas Muhammadiyah Malang Press

Winarno, Budi. 2008. Kebijakan Publik - Teori dan Proses. Jakarta : Buku Kita

Zuraida, Ida dan Hari Sih Advianto. 2011. Penagihan Pajak. Jakarta : Ghalia Indonesia 